JAPANESE JOURNAL OF INFLAMMATION EDITORIAL

\title{
Immunomodulating activities of bacterial cell surface components
}

Shozo Kotani

\section{細菌細胞表層成分の生体機能調節作用}

\author{
小谷 尚 三*
}

細菌，特にヒトをはじめとする動物に“寄生”する細菌の細胞表層部には，広義の免疫を 中心とする生体の機能にさまざまな影響を与光る種々の免疫調節物質(生体反応修飾物質) が局在している。この事実の背景には，宿主と細菌との間の悠久といってよいほどになが く, また一体ともいえる密接な, 細胞表層部を介しての関わりあいがあり, 細菌表層成分 の生体機能調節作用は, 宿主と細菌の相互作用を軸にした双方の“進化”のら元に成立し ているのではないとさえ考えられる。

細菌表層由来の免疫調節物質のなかで, もっとも研究が進んでいるのは, 汪とんどすべ ての細菌種に共通し，かつ表層部の骨骼構造である細胞壁ペプチドグリカン，ならびにグ ラム陰性菌に特徵的な表層成分である内毒素性りポ多糖だといえよう。それぞれの生物学 的作用を担う最小構造が, 前者については12年前に, 後者ではごく最近に, 化学合成によ って確定された。これらの研究成果が引き金となって，基礎および臨床・予防医学にわた る広い視点からの活発な研究が展開され，思いがけない発見をも含む多くの知見が日々集 積されつつある。しかし, これらの研究の経過, 現状, 将来の展望について具体的に述べ ることは，本闌の意図に合わないと思劣る。そこで，私のような若輩には似合わないこと を承知のら壳で, この領域の研究への私自身の関わりあいを述べさせていただく.

振り返ってみると，私が細胞表層に局在する免疫調節物質の研究に手を染めたのは，ち ょうど30年前であった。1956年に奈良医大の細菌学講座を担当することになった私は, 敗 戦から日の浅い時代の新設医大の例に漏孔ず，はなはだ不十分であった研究条件のもと で，はやりのテーマで研究を進めることは得策ではないと考光た。そこで当時ほとんど注 目されていなかった細菌細胞壁の生物学的作用の研究に取り組むこととした.

まず, 前任の阪大医学部公衆衛生学教室時代の研究テーマの一つ, 結核菌について, 当 時をで報告がなかった細胞壁の分離を試みた。 そうして，結核菌に特徴的で，かつ生物学 的に活性な菌体成分であるワックス Dならびにコードファクター(トレハロースマイコ レート ダイェステル）を含むワックスCが，細胞壁に局在することをはじめて明らかに した.

結核菌に限らず, 細菌細胞壁の生物学的作用の研究を進めるに当ってクリアーしなけれ ばならない問題点は, 細胞壁がその化学的ないし物理的特性に基づいて不溶性であるこ と, また寄生性細菌種の細胞壁は, 当然, 宿主に広く分布する溶菌酵素であるリゾチーム の作用を受けにくく，したがって，新しい溶菌酵素を自ら手にしなければならないことで あった．幸いに，作用点を互いに異にする 細胞壁溶解酵素 (ペプチドグリカン加水分解

* 大阪大学名誉教授・大阪医療技術学園 (校長)

Professor emeritus, Osaka University - Director, Osaka College of Medical Technology 


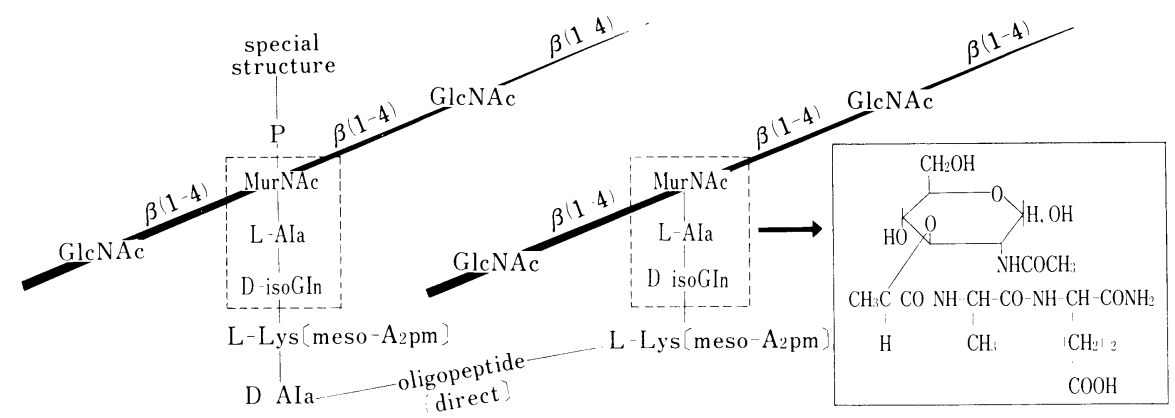

図 1 寄生性細菌種の細胞壁ペプチドグリカソひ構造モデル, 拉よびその要（かなめ）構造 で, かつペプチドグリカンの生物学的活性の大半を担ＭＭP の化学構造

Streptococcus pyogenes, Staphylococcus aureus などでは二塩基アミノ酸は L-リジン型

Escherichia coli, Mycobacterium tuberculosis では, [ ] 内に示すように, meso-2,6-ジ アミノピナリン酸 (meso- $\mathrm{A}_{2} \mathrm{pm}$ ) 型.

MurNAc: N-アセチールムラミン酸. GlcNAc：N-アセチールグルコサミン

酵素)をつくる複数の土壤菌を，細胞壁を唯一・の栄養源とした強化培養法により，分離す ることができた。

得られた土壌菌がつくる酵素を用いて，BCGの細胞壁を“解体”し，当時アジュバント 作用を示すワックスDを保有しないとされていた BCG にも，酵素処理によるペプチドグ リカンの可溶化に伴って適当な有機溶媒に“溶解”するようになる結合脂質として，アジュ バント活性の強いワックス Dが存在することを確認した。

悔いが残るのは, この研究の過程で得た水溶性画分についても, アジュバント作用の検 定を行いながら，暖房設備の不備のために，笑験に供したモルモットの大部分を死亡さ せ，乙かも動物を改めて購入する費用に事欠いたために，再実験を断念せざるを党なかっ たことである。結果として， ミコバクテリア川来の water soluble adjuvant (WSA)の記 載に当って, フランスの Lederer, Chedid 博士:らのグループに遅れをとった。なにぶんに も, 日本全体が敗戦の痛手から十分立ち直っていない時代のことであり，1959年にェール 大学に留学した際の奈良医大教授としての月給が 100〜150ドル 相当 $(\mathrm{NIH}$ のフェローと しての奖学金の月額は 450 ドル）にすぎなかったことを思い起こすと，まことに今昔の感 に絶えない。

1964年，歯学部教授として大阪大学にもどったが，このころになると，日本経済全体が かつてない好況に恵まれ，加えて，多くの先輩のかたがたのご理解を得て，研究設備の充 実, 研究費の獲得にさ注ど苦労することもなく, 奈良医大時代からの研究を順調に進める ことができた。

こうして，1973年には，Staphylococcus aureus 拈よび Lactobacillus plantarum の細胞壁ペプ チドグリカンを複数の酵素で処理して得たペブチドグリカンのモノマー(それぞれ L-リジ ン型拈よび 2,6-ジアミノピメリン酸型)が，もっとも強力なアジュバントとして周知の Freund 完全アジュバント中の key substance であるミコバクテリアの作用(特に遅延型ア レルギーを誘導する活性)を，完全に代行しらることを明らかにすることができた．

大変好運であったのは，1973年の秋に，有機天然化合物の合成研究の権威であられる芝 哲夫教授(阪大理学部)に巡り合えたことである。別の用向きで来室された先生に，上述の 私どもの研究について怙話ししたところ，学問的好奇心の旺盛な先生に大変興味を持って いただくことができ，それならば，化学合成によって最小有効構造の決定を試みようとい 


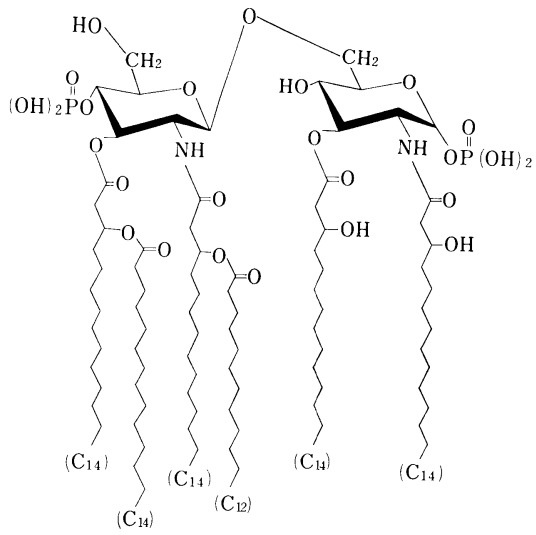

図 2 Escherichia coli 型りピド A の 化学構造

$\beta$ (1-6) D-グルコサミンジサッカ

リド $1,4^{\prime}$ ビスリン酸に, ( R $)-3$-テト

ラデカノイルオキシテトラデカノイ

ル $\left[\mathrm{C}_{14}-\mathrm{O}-\left(\mathrm{C}_{14}\right)\right],(\mathrm{R})-3-$ ドデカノ

イルオキシテトラデカノイル $\left[\mathrm{C}_{14}{ }^{-}\right.$

$\left.\mathrm{o}-\left(\mathrm{C}_{12}\right)\right]$ 打よび $(\mathrm{R})-3$ - ヒドロキシ

テトラデカノイル $\left(\mathrm{C}_{14} \mathrm{OH}\right)$ 基が,

四に示すようにエステル拉よび

ミド結合している。

らことになった。こうして，1974年夏にミュンヘンでの開催が予定され，かつ坐長，演者 として招請されていた, 細胞壁の国際シンポジゥムでの発表を目標として, 精力的な合成 研究が芝研究室で進められることとなった。しかしわずか 10 日間ばかりのずれ(合成品の 生物学的作用の検定を担当した私どもの側での，標品の取り違いという単純ミスによる） で，シンポジウムの当日には決定的なデータを示すことができずに終わった．会場外の芝 生での談笑の間に，私どもが合成研究を開始していることを知ったよきライバルの Lederer 教授は，急遽会場の黒板を使って，手書きで $N$-アセチルムラミル-L-アラニル-D-イソ グルタミン(MDP) ガペプチドグリカンのアジュバント作用を担う最小有効構造であると いう，扔とらくは予定外(スライドを用意していなかったことからみて)の発表を行った。 このような経緯で，MDP のアジュバント作用についての，私どもの原著論文の発表は， 1974年の Lederer 博士らの Biochem. Biophys. Res. Commun. 誌での発表に対して, 翌 1975年になった。

上記シンポジゥムで発表しえなかった合成ムラミルペプチドに関する研究結果をシンポ ジゥムの記録(Z. Immunitätsforsch.)に記載するという私どもの不手際や, 私どもがMDP の特許を申請しているとの事実無根の䛊解もあり, Lederer 教授との関係が気まずくなっ たこともあった。しかし，この誤解も氷解した現在では，合成MDP のアジュバント作用 は，まず Lederer 教授らにより，やや遅れて，しかし独立して，小谷・芝らにより明らか にされたことが，国際的にもほぼ一致して認められている。

この発見が引き金となって，MDPを親化合物とするムラミルペプチドならびにその類 似体, 誘導体の生物学的作用の研究は, 過去10年間に飛躍的に進展し, 新しい研究論文が 踵を接するごとく発表された。このようにして選ばれた化合物が，ワクチン，特に人工ワ クチンのアジュバントとして, あるいは, 微生物感染や腫瘍の発生, 進行に対する生体の 防御機構を非特異的に高める薬剤として, 予防・臨床医学の現場で実用される日も, そう 遠くないのではないかと期待される。

一方，内毒素については，その毒作用などの生物学的作用の大部分を担らリピドAが， これまた芝研究室で $\beta(1-6)$ D-グルコサミン bis リン酸の $\beta$-アシルオキシアシル誘導体 として，世界に先駆けて合成され，内毒素の活性中心をめぐる約 30 年間にわたる論議に決 定的な終止符が打たれた。私どもも，西ドイッのフライブルク/ボルステルグループお よび北里研究所の本間 遜博士のグループとともに，合成標品の生物学的作用の研究を分 担し, 内毒素研究の大きなマイルストーンともいえるリピドAの合成研究に参画する好運 
に恵まれた。ここ 2,3 年間のリピド Aをめぐる研究の進展について述べる余裕がないの が残念であるが，大阪帝大を卒業直後に学位論文のテーマとして選んだ1945年当時の内毒 素, 特に作用を担う構造の化学的実体についての情報の貧弱さを思い起こし, 遺伝子工学 の成果などの陰にともすれば隠れがちではあるが, 生命科学の進歩に果たす合成研究の重 要性を改めて実感している。

さて，私は，本年 3 月末に大阪大学を停年退官した。多数のよき先輩，同僚，学内外の 有能な共同研究者に囲まれて，私個人の実力以上の研究成果をあげえたと自負している。 過去の研究生活を振り返るようになっては, 研究者としての年貢の収めどきのようにも思 えるし，現在，身柄を預けている大阪医療技術学園では，直接には実験に従事することは できない。しかし，幸いに理事長の温い理解のもとに，十分な研究活動の時間を与兄られ， かつ各方面からのご援助を得て，研究意欲を満足させていただいている。ムラミルペプ チド，合成リピドAとその類似体・誘導体などの研究の継続に加えて, 目下, Streptococcus pyogenes の細胞表層成分である両親媒性物質, リポタイコ酸やミコバクテリア由来の, 内 毒素とは化学的にはまったく異なるが，類似した生物学的作用を示す両親媒性の免疫調節 物質について，活性中心の化学構造の決定・合成に夢をつないでいるしだいである.

以上, 私個人の研究履歴を述べることに終始し, 与えられた誌面を大幅にはみ出してし まったが, 最後に, 正常細菌フローラのメンバーの細菌表層成分をビタミンの一種とし て，あるいは“内因性”の免疫調節因子 (endogenous immunomodulator) として捉光，免疫 担当細胞に対してのみでなく，中枢神経系などにも働く活性因子として，これら物質の “生理的”な役割を究めようとする研究が急速に展開する兆しが見えることを指摘して扣き たい，古典的な伝染病が少なくとも先進諸国では影をひそめ，通常の細菌感染症の多くに 対しても対処が可能となった現在，徒らに“寄生性”細菌を敵視する姿勢を改め，よきコン パニオンとして朓め直す研究に, 広い領域の研究者が参加されることが望まれる。

標記の研究領域に興味をお持ちの読者のために, 筆者らの最近の総説, 解説(入手しやすい和書)を あげておく.

1）高田春比古，小谷尚三：ムラミルペプチドの免疫薬理作用. 免疫薬理 3：279-287, 1985.

2）高田春比古, 小谷尚三：合成リピド Aの生物学的活性.. 免疫薬理 3: 288-297, 1985.

3）高田春比古, 小谷尚三：ムラミルペプチドの睡眠作用. 免疫薬理 3: 465-469, 1985.

4) 高田春比古, 小谷尚三: 特異免疫の強化一ムラミルベブチドとワクチン. 病態生理 4: 630-640, 1985.

5) 小谷尚三：細菌細胞表層成分ならびにその合成対応物 (Synthetic Counterpart) の生物学的活性，細菌学は ここまで進んだ(蜂須賀養悦監修). 朵根出版, 東京, 1986, p 130-149.

6）高田春比古，小谷尚三：生体防御活性化物質の合成とその特性. 生体防御 3：65-82, 1986.

7）高田春比古, 小谷尚三：合成リピド A ならびにそのアナログの生物学的活性. 蛋白質, 核酸, 酵素 31：361373, 1986.

8）高田春比古，小谷尚三：生体防御機能の微生物に上る修飾. 日本臨床 44:1972-1980, 1986. 